\title{
Preparation of synthetic carnallite and amorphous silica from chromite beneficiation plant tailings
}

\section{Introduction}

Chromite concentration plant tailings have an important potential for the production of magnesium based materials because these tailings consist of high magnesium-containing lateritic ores. Besides, contents of the $\mathrm{SiO}_{2}$ and precious metals such as nickel and chromium enhance the worth of these type tailings (Top and Yildirim 2015).

Turkey is the sixth largest chromite ores exporter in the world. These ores have been mined from mostly serpentinized ultramafic bodies, discontinuously spread all over the country (Cicek and Cocen 2002; Agacayak et al. 2007; Vapur et al. 2014). Chromite mineralizations, which are one of the most important metallic deposits in Turkey, are clustered in Aladag County of Adana District. Kizllyuksek deposite of Aladag, where a reserve has 198000000 tonnes and 5.37\% $\mathrm{Cr}_{2} \mathrm{O}_{3}$ grade, is recently explored by the Mineral Research \& Exploration General Directorate (MTA) and this deposit is the largest deposit in the world in terms of ophiolitic chromites (MTA 2015).

Amount of the chromite ores concentration plant tailings processed by 7 plants in this area from 2004 to 2010 are seen in Table 1. Also the tailings' quantities of the biggest and

* Ph.D. Student; M.Sc. Eng., Mining Engineering Department, Cukurova University, 01330, Adana,

Turkey; e-mails: sonficyus@gmail.com; stop@cu.edu.tr

** Professor, Mining Engineering Department, Cukurova University, 01330, Adana, Turkey;

e-mail: mehyil@cu.edu.tr 
old established 2 plants in Aladag area for the last 10 years is seen in Fig. 1. It is obvious that quantity of the tailings increased with every passing year.

Table 1. Amount of the tailings generated by the mining companies in Aladag by years (metric ton)

Tabela 1. Ilość odpadów wytwarzanych przez firmy górnicze w Aladag w latach 2004-2010 (tony metryczne)

\begin{tabular}{|l|c|c|c|c|c|c|c|c|}
\hline \multicolumn{1}{|c|}{ Years } & 2004 & 2005 & 2006 & 2007 & 2008 & 2009 & 2010 & Total \\
\hline Run-of-mine & 187806 & 191075 & 238786 & 366223 & 566324 & 826083 & 1934276 & 4310573 \\
\hline Tailings & 168586 & 170547 & 217482 & 324750 & 501590 & 748997 & 1766581 & 3898533 \\
\hline
\end{tabular}

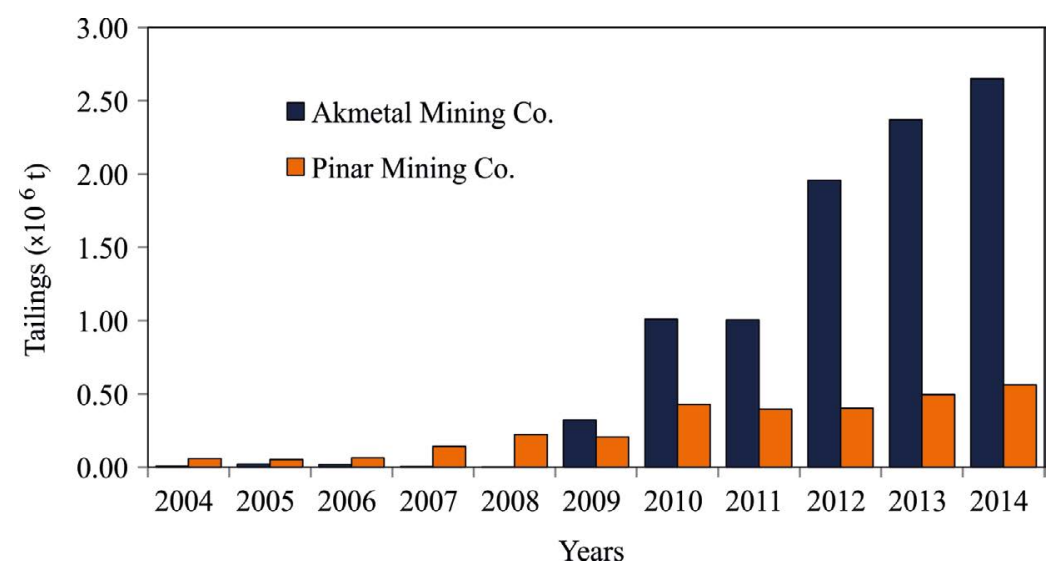

Fig. 1. Tailing quantities of the biggest 2 plants in the last 10 years

Rys. 1. Ilości odpadów w dwóch największych zakładach w okresie ostatnich 10 lat

Serpentine, rock which composes largely of serpentine minerals (include three minerals chrysotile, lizardite, and antigorite, all of which have similar compositions based on the presence of the main $\mathrm{Mg}_{3} \mathrm{Si}_{2} \mathrm{O}_{5}(\mathrm{OH})_{4}$ core, and differ slightly in the degree of substitution of $\mathrm{Mg}$ by $\mathrm{Fe}$ and $\mathrm{Al}$ ), can be found in alpine-type settlings and as rocks dredged from the ocean bottom (El-leef et al. 2012). Serpentine is characterized by high levels of magnesium (ca. $35 \mathrm{wt} \% \mathrm{MgO}$ ), low calcium and aluminium content (ca. $1-4 \mathrm{wt} \% \mathrm{CaO}$ and $\mathrm{Al}_{2} \mathrm{O}_{3}$ ). This mineral can be utilized in numerous applications such as soil amelioration, extraction of amorphous silicate and pure magnesium compounds (Zengin et al. 2009; Fedorockova et al. 2012; Gao et al. 2014).

There are three magnesium production processes as known: silicothermal, carbothermal and electrolytic. In electrolytic route, magnesium metal is produced from magnesium-containing salts such as carnallite, bischofite, etc. by molten salt electrolysis method as seen at Equations (1) and (2): 


$$
\begin{gathered}
\mathrm{Mg}^{2+}+2 e^{-} \rightarrow \mathrm{Mg}_{(\text {solid })} \\
2 \mathrm{Cl}^{-}+2 e^{-} \rightarrow \mathrm{Cl}_{2 \text { (gas) }}
\end{gathered}
$$

The most important industrial magnesium production project by utilization of serpentine is Magnola Process by now. In the Magnola process, the leaching reaction generated soluble magnesium and an amorphous silica reaction product. The magnesium is converted from a silicate form into molten anhydrous magnesium chloride and then electrolyzed in a multipolar cell (Polmear 1999; Dutrizac et al. 2000; Watson et al. 2000). Synthetic amorphous silica has a wide range of usage area for industrial applications as filler in rubber and tires, whiteness agent and printability improver in paper and paint, etc. Also, materials containing high grade $\mathrm{SiO}_{2}$ can be utilized by photovoltaic industry which uses silicates to make solar panels (Khattak et al. 2001; Xakalashe and Tangstad 2011).

The most suitable treatment method to remove impurities from magnesium chloride solutions is fractional precipitation of hydroxides. Purified magnesium chloride solutions must be approximately neutral and the content of impurities in them must be no longer than $\left(\mathrm{g} / \mathrm{dm}^{3}\right): 0.26 \mathrm{Fe}, 0.08 \mathrm{Si}, 0.003 \mathrm{Ni}, 0.004 \mathrm{Cu}, 0.03 \mathrm{Mn}, 0.013 \mathrm{Al}, 0.009 \mathrm{Ti}$ and $0.004 \mathrm{Cr}$ (Strelets 1977; Gladikova et al. 2008).

In the present study; magnetic separation, leaching, precipitation and evaporation tests were consecutively performed. Mineral carnallite and amorphous silica were obtained. There are a lot of studies for recovering chromite from the tailings by magnetic separation in the literature (Guney et al. 2001; Aslan and Kaya 2009; Tripathy et al. 2013). But these studies only intend to recover chromite content. Present study is separated from the others by providing 3 products from the tailings: carnallite, amorphous silica and chromite.

\section{Experimental}

\subsection{Materials}

Chromite ore beneficiation plant tailings of Pinar and Akmetal companies located in Aladag district of Adana in Turkey were chosen as materials. In the plants, the tailings are divided into two fractions by sizes: coarse $(\mathrm{d} 50: 0.38 \mathrm{~mm})$ and fine tailings $(\mathrm{d} 50: 0.18 \mathrm{~mm})$. The fine tailings are about $60 \%$ of the total tailings. The fine tailings were used in the all experimental study.

As can be seen in Table 2, the loss on ignition rate is more than $15 \%$ and this confirms that the tailings are strongly serpentinized according to Bron et al. (1967). It was determined that the fine sized tailings consist of antigorite (serpentine), chromite, manganese oxide, talc and montmorillonite minerals by Rigaku Minflex II X-Ray Diffractometer (Fig. 2). 
Table 2. Chemical analysis of the fine sized tailings

Tabela 2. Analiza chemiczna odpadów drobnoziarnistych

\begin{tabular}{|l|c|}
\hline Component & $\%$ \\
\hline $\mathrm{SiO}_{2}$ & 38.55 \\
\hline $\mathrm{MgO}$ & 30.55 \\
\hline $\mathrm{Fe}_{2} \mathrm{O}_{3}$ & 10.53 \\
\hline $\mathrm{Cr}_{2} \mathrm{O}_{3}$ & 3.44 \\
\hline $\mathrm{Al}_{2} \mathrm{O}_{3}$ & 0.77 \\
\hline $\mathrm{MnO}$ & 0.47 \\
\hline $\mathrm{CaO}$ & 0.44 \\
\hline $\mathrm{NiO}$ & 0.07 \\
\hline Loss on ignition & 15.18 \\
\hline
\end{tabular}

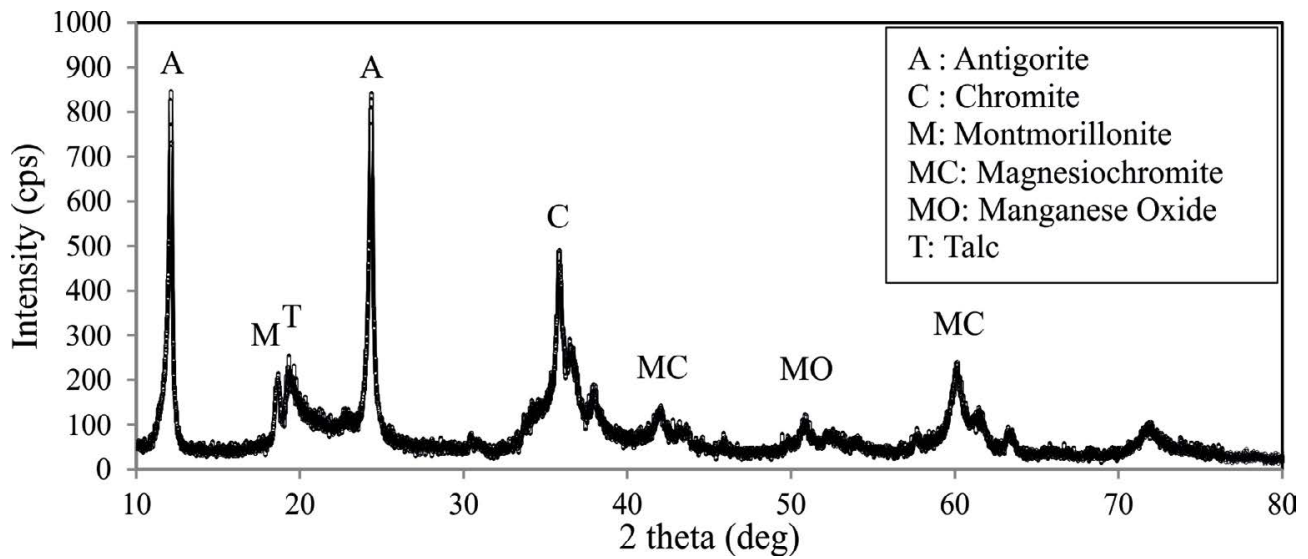

Fig. 2. XRD pattern of the fine sized tailings

Rys. 2. Dyfraktogram rentgenowski XRD drobnych kruszyw

Fine samples which chemical analysis is demonstrated in Table 2 were ground by using $10.8 \mathrm{~kg}$ of steel balls, $0.35 \mathrm{~kg}$ of the samples at $72 \%$ solid/liquid ratio and $5 \mathrm{~min}$ in the laboratory scale ball mill and then used in the present study. Metallic contamination resulted from the milling was not important because metallic impurities will have discarded from the products in the following magnetic separation and precipitation tests. Grain size distributions of three fractions are seen in Fig. 3. 


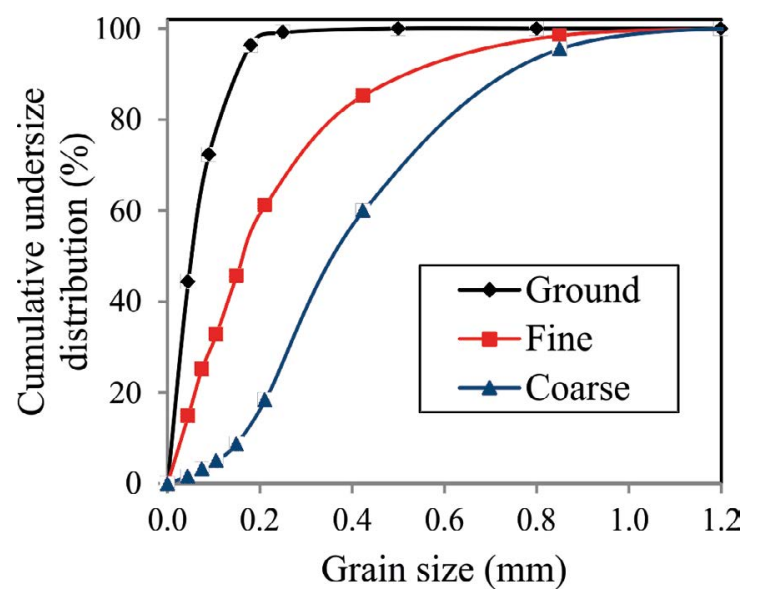

Fig. 3. Cumulative undersize distribution of the fine, coarse and ground tailings

Rys. 3. Skumulowana krzywa podsitowa ziarn drobnych, grubych i zmielonych odpadów

\subsection{Methods}

One-factor-at-a-time (OFAT) analysis was used to enlighten how the factors effect in the experiments. OFAT analysis consists of selecting a starting point, or baseline set of levels, for each factor, and then successively varying each factor over its range with the other factors held constant at the baseline level. After all tests are performed, a series of graphs are usually constructed showing how the response variable is affected by varying each factor with all other factors held constant.

In the tests, most of the magnetic minerals were discarded by using Eriez L4-20 WHIMS laboratory model high intensity wet magnetic separator at first. The pulp conditioned in a $500 \mathrm{~cm}^{3}$ beaker being agitated by magnetic stirrer was fed into the magnetic separator. Magnetic separation products were dried and weighed. Non-magnetic phase was leached with $\mathrm{HCl}$ and amorphous silica was achieved by filtration as solid material. The reaction between $\mathrm{HCl}$ and the tailings was performed in a $250 \mathrm{~cm}^{3}$ beaker equipped with a thermometer and a magnetic stirrer under atmospheric pressure. $\mathrm{pH}$ of the leach solution was raised by adding solid $\mathrm{Mg}(\mathrm{OH})_{2}$ and the impurities were precipitated. After the filtration, the purified $\mathrm{MgCl}_{2}$ solution was mixed with solid $\mathrm{KOH}$ pellets and the evaporation was begun to synthesize carnallite (Fig. 4).

Solid/liquid ratio, stirrer speed, stirring time and magnetic field strength were chosen as the varying parameters in the magnetic separation tests. Molarity of $\mathrm{HCl}$, leaching time, stirrer speed, solid/liquid ratio and temperature were selected as the parameters to be optimized in the leaching tests. During the all tests, $\mathrm{Fe}$ and $\mathrm{Mg}$ contents were analysed with 


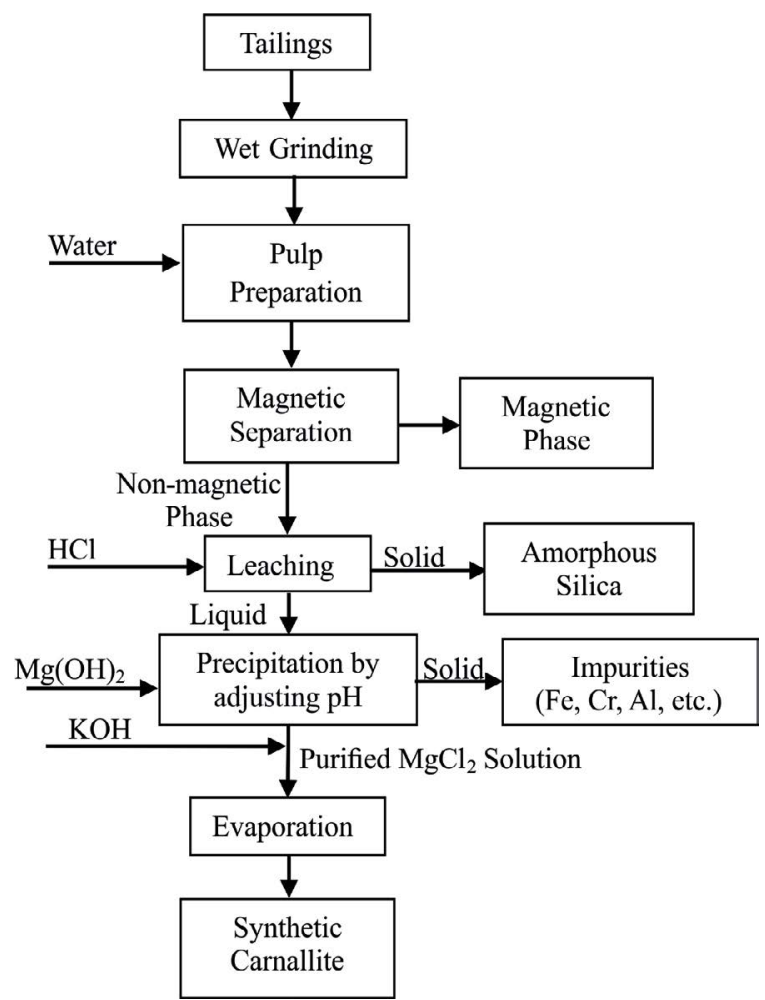

Fig. 4. Basic flow sheet of the experimental study

Rys. 4. Schemat badań otrzymywania karnalitu

EDTA drop titration method and the other elements were determined by Perkin Elmer PinAAcle $900 \mathrm{H}$ atomic adsorption spectrophotometer (AAS). Analytic grade chemicals of Merck, Sigma Aldrich, Alfa Aesar with tap water in the Cukurova University laboratories were used throughout the study. $\mathrm{Mg}$, Fe and the other impurities in the tap water were specifically excluded from the calculations. This method was chosen because it would not be easy to put that study into effect with economic reasons. Distilled water would not be used if beneficiation of these tailings would be performed in the industrial scale. Moreover, all of the impurities except calcium and magnesium ions in tap water will have precipitated by increasing the $\mathrm{pH}$ in the method applied by this study. 


\section{Results and Discussion}

\subsection{Magnetic Separation}

It is known that chromite dissolve in $\mathrm{HCl}$ solutions almost never. Traditional chromite dissolution methods mostly depend on hydrofluoric $(\mathrm{HF})$, perchloric $\left(\mathrm{HClO}_{4}\right)$, phosphoric

a)

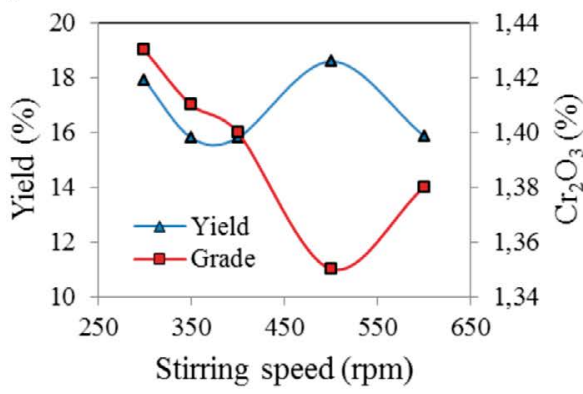

c)

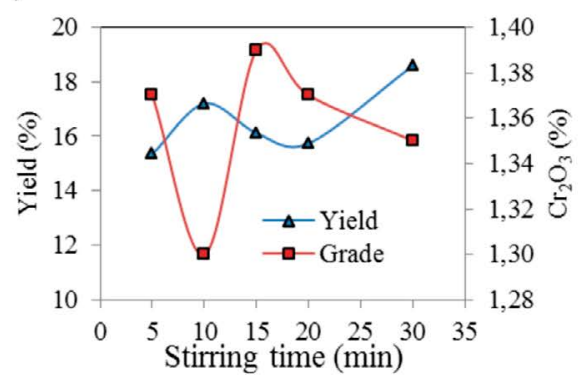

b)

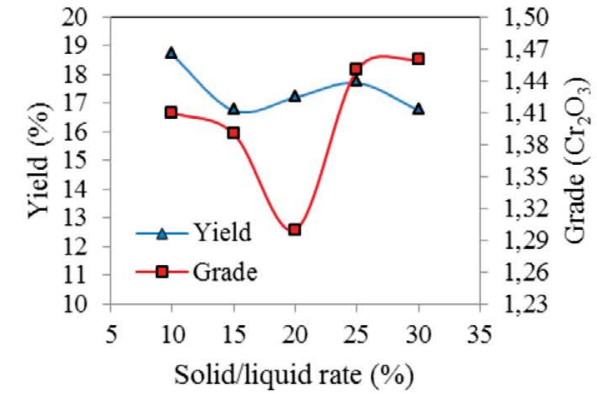

d)

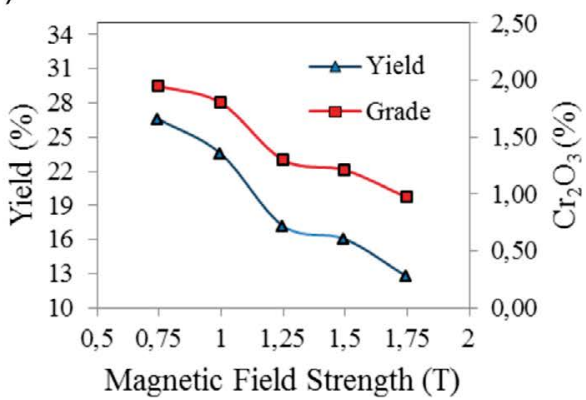

Fig. 5. a) Effect of the stirring speed on chromite yield and grade of the non-magnetic fraction (solid/liquid rate: $20 \%$; stirring time: $10 \mathrm{~min}$; magnetic field strength: $1.25 \mathrm{~T}$ ),

b) Effect of the stirring time on chromite yield and grade of the non-magnetic fraction (solid/liquid rate: $20 \%$; magnetic field strength: $1.25 \mathrm{~T}$; stirring speed: $500 \mathrm{rpm}$ ),

c) Effect of the solid rate on chromite yield and grade of the non-magnetic fraction (solid/liquid rate: $20 \%$; stirring time: $10 \mathrm{~min}$; magnetic field strength: $1.25 \mathrm{~T}$ ),

d) Effect of magnetic field strength on chromite yield and grade of the non-magnetic fraction (solid/liquid rate: 20\%; stirring time: $10 \mathrm{~min}$; stirrer speed: $500 \mathrm{rpm}$ ).

Rys. 5. a) Wpływ szybkości mieszania na wydajność i stopień chromitacji frakcji niemagnetycznej (stosunek ciało stałe/ciecz: 20\%, czas mieszania: 10 minut, natężenie pola magnetycznego: $1,25 \mathrm{~T}$ );

b) wpływ czasu mieszania na wydajność i stopień chromitacji frakcji niemagnetycznej (stosunek ciało stałe/ciecz: 20\%, natężenie pola magnetycznego: 1,25 T, szybkość mieszania: 500 obr./min);

c) wpływ stosunku ciała stałego na wydajność chromitu i stopień chromitacji frakcji niemagnetycznej (stosunek ciało stałe/ciecz: $20 \%$, czas mieszania: $10 \mathrm{~min}$, natężenie pola magnetycznego: 1,25 T);

d) wpływ pola magnetycznego na wydajność i stopień chromitacji frakcji niemagnetycznej

(stosunek ciało stałe/ciecz: 20\%, czas mieszania: 10 minut, szybkość mieszadła: 500 obr./min) 
$\left(\mathrm{H}_{3} \mathrm{PO}_{4}\right)$ and sulphuric $\left(\mathrm{H}_{2} \mathrm{SO}_{4}\right)$ acids in addition to alkali leaching (Geveci et al. 2002; Chen et al. 2014; Spectroscopyonline.com 2014). Therefore, main purpose of the magnetic separation was particularly to eliminate the chromite content in addition to the iron and manganese contents before the leaching. Chromite yield and grade of the non-magnetic fraction were taken into consideration since non-magnetic fraction will be used in the following leaching stage.

Effects of the stirrer speed, stirring time, solid/liquid ratio and magnetic field strength on the magnetic separation were investigated in succession. The best result for stirring speed tests was obtained at $500 \mathrm{rpm}$ which chromite grade of the non-magnetic phase was minimum (Fig. 5a). In the stirring time tests, 10 min stirring time was determined as convenient time (Fig. 5b). The best result in the solid/liquid ratio determining stage was $20 \%$ which chromite grade of the non-magnetic phase was the lowest (Fig 5c). The chromite grade and yield of the non-magnetic material decreased as the magnetic field strength increased (Fig. 5d). It was found that the stirrer speed and the magnetic field strength were effective parameters on magnetic separation rather than the others.

Optimum conditions for the magnetic separation were found as $500 \mathrm{rpm}$ stirrer speed, $20 \%$ solid/liquid ratio, $10 \mathrm{~min}$ stirring time and $1.75 \mathrm{~T}$ magnetic field strength. Chemical analysis of the non-magnetic material acquired from the above mentioned conditions is seen in Table 3. The results indicated that $85.75 \%$ of $\mathrm{Cr}_{2} \mathrm{O}_{3}, 91.22 \%$ of $\mathrm{MnO}$ and $64.71 \%$ of $\mathrm{Fe}_{2} \mathrm{O}_{3}$ were removed. Iron removal was low in the magnetic separation in comparison to the other magnetic contents because the iron content, which can be found in the mineral antigorite $\left((\mathrm{Mg}, \mathrm{Fe})_{3} \mathrm{Si}_{2} \mathrm{O}_{5}(\mathrm{OH})_{4}\right)$ as the element $\mathrm{Fe}$, could not be separated by the magnetic separation that is a physical method. Obtained non-magnetic material was $51.61 \%$ of the original sample by weight. It was dried and collected for using in the next leaching stage. Also,

Table 3. Chemical analysis of the non-magnetic material

Tabela 3. Analiza chemiczna materiału niemagnetycznego

\begin{tabular}{|l|c|}
\hline \multicolumn{1}{|c|}{ Component } & $\%$ \\
\hline $\mathrm{SiO}_{2}$ & 40.04 \\
\hline $\mathrm{MgO}$ & 33.83 \\
\hline $\mathrm{Fe}_{2} \mathrm{O}_{3}$ & 7.20 \\
\hline $\mathrm{Cr}_{2} \mathrm{O}_{3}$ & 0.95 \\
\hline $\mathrm{Al}_{2} \mathrm{O}_{3}$ & 0.72 \\
\hline $\mathrm{MnO}$ & 0.08 \\
\hline $\mathrm{CaO}$ & 0.94 \\
\hline $\mathrm{NiO}$ & 0.05 \\
\hline Loss on ignition & 16.19 \\
\hline
\end{tabular}


the magnetic material was recovered with $6.10 \% \mathrm{Cr}_{2} \mathrm{O}_{3}$ grade and $85.75 \% \mathrm{Cr}_{2} \mathrm{O}_{3}$ recovery yield. It is thought that $\mathrm{Cr}_{2} \mathrm{O}_{3}$ cannot be separated completely by any physical beneficiation method even if particle sizes are reduced. Chromium in the samples is not only in the chromite ore form which has $\mathrm{FeCr}_{2} \mathrm{O}_{4}$ formula but also in the magnesiochromite forms presented by $\mathrm{MgCr}_{2} \mathrm{O}_{4}$ or $\mathrm{MgFeCr}_{2} \mathrm{O}_{4}$ formulas.

\subsection{Leaching}

The main leaching reaction is shown in Equation (3):

$$
\mathrm{Mg}_{3} \mathrm{Si}_{2} \mathrm{O}_{5}(\mathrm{OH})_{4}+6 \mathrm{HCl} \rightarrow 3 \mathrm{MgCl}_{2}+2\left(\mathrm{SiO}_{2}\right)_{(\text {amorphous })}+5 \mathrm{H}_{2} \mathrm{O}
$$

The dissolutions of $\mathrm{Mg}, \mathrm{Fe}, \mathrm{Ca}, \mathrm{Mn}, \mathrm{Cr}$ and $\mathrm{Ni}$ in $\mathrm{HCl}$ solutions were studied. Non-magnetic material was leached at different acid molarities, temperatures, solid/liquid ratios, stirrer speeds and time intervals, respectively. As seen in Fig. 6a, extraction of the elements was mostly increased in direct proportion to $\mathrm{HCl}$ concentration, but dissolved $\mathrm{Mg}^{2+}$ ions were steady over the $7 \mathrm{M}$ of $\mathrm{HCl}$ solution while $\mathrm{Ca}^{2+}$ ions were completely dissolved for the each $\mathrm{M}$ of $\mathrm{HCl}$. The experiments plotted in Fig. $6 \mathrm{~b}$ revealed that the stirrer speed was not significant in the leaching between the speeds $150-550 \mathrm{rpm}$. The extraction rates were found to be dependent on the temperature, especially over $60^{\circ} \mathrm{C}$ (Fig. 6c). In spite of the high temperatures, chromium still did not passed into the leach solution. All the contents were extracted from the solid sample at $90^{\circ} \mathrm{C}$ almost completely except chromium and silica. From Fig. 6d, it can be said that leaching of the sample was substantially completed at the first $30 \mathrm{~min}$. Then, extraction rates slightly increased. As shown in Fig. 6e, dissolution rates were decreased as the solid/liquid ratios were increased. The rates of the $\mathrm{Mg}^{2+}$ ions had dramatic drop over $11 \%$, surprisingly. The optimal conditions were revealed as following: stirrer speed: $300 \mathrm{rpm}$; stirring time: $30 \mathrm{~min}$; temperature: $90^{\circ} \mathrm{C} ; \mathrm{HCl}$ concentration: $7 \mathrm{M}$, solid/liquid ratio: $11 \%$ (Table 4 ).

Table 4. Content of the leach solution at optimum conditions

Tabela 4. Zawartość roztworu ługującego w warunkach optymalnych

\begin{tabular}{|c|c|c|c|c|c|c|}
\hline Element & $\mathrm{Mg}$ & $\mathrm{Fe}$ & $\mathrm{Cr}$ & $\mathrm{Mn}$ & $\mathrm{Ca}$ & $\mathrm{Ni}$ \\
\hline $\mathrm{mg} / \mathrm{L}$ & 6744.00 & 1470.00 & 4.12 & 11.60 & 243.72 & 12.20 \\
\hline
\end{tabular}

The extraction rates were found to be dependent on temperature and $\mathrm{HCl}$ concentration rather than leaching time and solid/liquid rate. There was no correlation between the stirrer speed and the leaching. 
a)

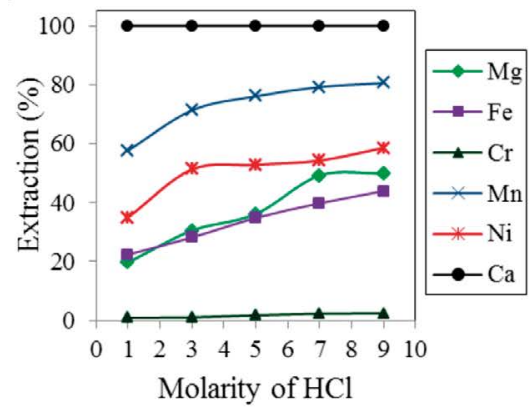

c)

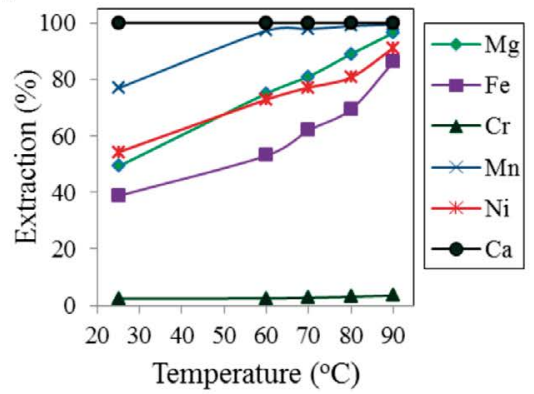

e)

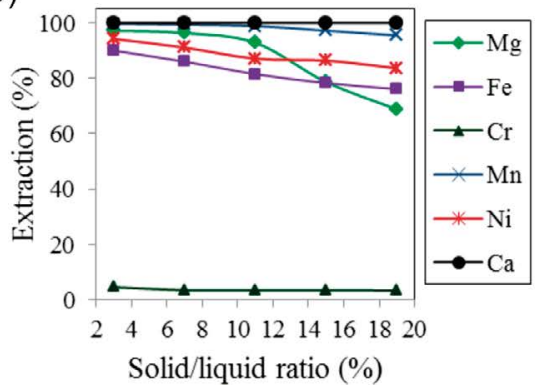

b)

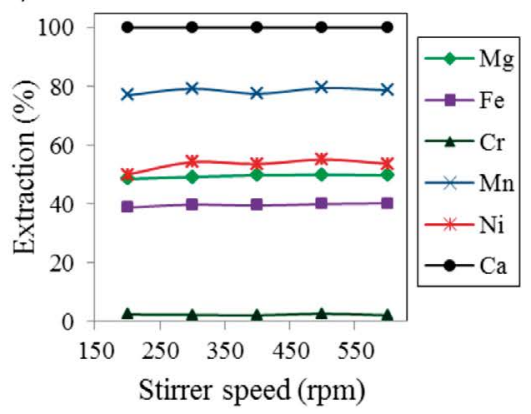

d)

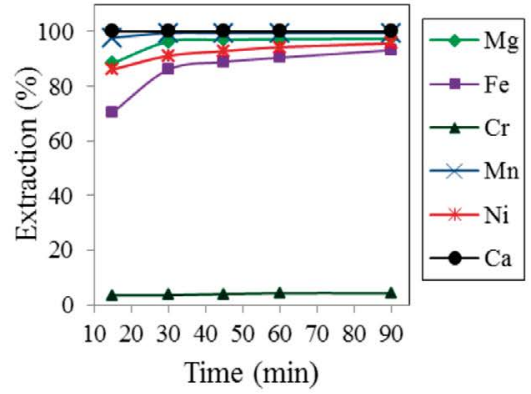

f)

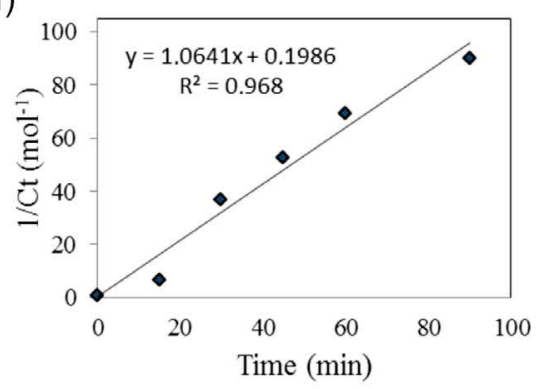

Fig. 6. a) Effects of $\mathrm{HCl}$ concentration (solid/liquid rate: 7\%; stirring time: $30 \mathrm{~min}$; stirrer speed: $300 \mathrm{rpm}$, temperature: $25^{\circ} \mathrm{C}$ ),

b) stirrer speed (solid/liquid rate: $7 \%$; stirring time: $30 \mathrm{~min} ; \mathrm{HCl}$ concentration: $7 \mathrm{M}$, temperature: $25^{\circ} \mathrm{C}$ ), c) temperature (solid/liquid rate: 7\%; stirring time: $30 \mathrm{~min}$; stirrer speed: $300 \mathrm{rpm} ; \mathrm{HCl}$ concentration: $7 \mathrm{M}$ ), d) time (solid/liquid rate: $7 \%$; stirrer speed: $300 \mathrm{rpm}$; temperature: $90^{\circ} \mathrm{C} ; \mathrm{HCl}$ concentration: $7 \mathrm{M}$ ),

e) solid/liquid rate (stirrer speed: $300 \mathrm{rpm}$; stirring time: $30 \mathrm{~min}$; temperature: $90^{\circ} \mathrm{C} ; \mathrm{HCl}$ concentration: $7 \mathrm{M}$ ) on leaching and f) the second order dissolution kinetics of magnesium

Rys. 6. a) Wpływ stężenia $\mathrm{HCl}$ (stosunek ciało stałe/ciecz: 7\%, czas mieszania: 30 minut, szybkość mieszadła: $300 \mathrm{obr} / \mathrm{min}$, temperatura: $\left.25^{\circ} \mathrm{C}\right)$; b) szybkość mieszania

(stosunek ciało stałe/ciecz: $7 \%$, czas mieszania : $30 \mathrm{~min}$, stężenie $\mathrm{HCl}: 7 \mathrm{M}$, temperatura: $25^{\circ} \mathrm{C}$ )

c) temperatura (ciało stałe/ciecz: 7\%, czas mieszania: 30 min, szybkość mieszadła: 300 obr./min, stężenie HCl: 7 M); d) czas (stosunek ciało stałe/ciecz: 7\%, szybkość mieszadła: $300 \mathrm{obr} . / \mathrm{min}$, temperatura: $90^{\circ} \mathrm{C}$, stężenie $\mathrm{HCl}: 7 \mathrm{M}$ ), e) stała prędkość mieszania: $300 \mathrm{obr} / \mathrm{min}$, czas mieszania: 30 minut, temperatura: $90^{\circ} \mathrm{C}$, Stężenie $\mathrm{HCl}: 7 \mathrm{M}$ ) na ługowanie; f) kinetykę rozpuszczania magnezu drugiego rzędu 
The magnesium dissolution from serpentine in $\mathrm{HCl}$ solutions was described in the form of Equation (4) by Teir et al. (2007):

$$
\mathrm{HCl}+\frac{1}{6} \mathrm{Mg}_{3} \mathrm{Si}_{2} \mathrm{O}_{5}(\mathrm{OH})_{4} \rightarrow \frac{1}{2} \mathrm{Mg}^{+2}+\mathrm{Cl}^{-}+\frac{1}{3} \mathrm{SiO}_{2}+\frac{5}{6} \mathrm{H}_{2} \mathrm{O}
$$

Fig. $6 \mathrm{f}$ was created by using molar dissolution rates of magnesium in Fig $6 \mathrm{~d}$ which temperature of the leaching was constant. The reaction of the leaching process was found to be pseudo second order. Rate constant $(\mathrm{k})$ of this reaction was determined as 1.0641 which is the slope of linear line in Fig 6f. It was detected that Equation (5) can be written to explain magnesium dissolution from these type tailings:

$$
\frac{1}{c_{t}}=k t+\frac{1}{c_{o}}
$$

$\Leftrightarrow C t-$ equilibrium concentration $\left[\mathrm{mg} / \mathrm{dm}^{3}\right]$,

$C_{o}-$ initial concentration $\left[\mathrm{mg} / \mathrm{dm}^{3}\right]$,

$t$ - time [min],

$k-$ rate constant $\left[\mathrm{dm}^{3} / \mathrm{mg} \cdot \mathrm{min}\right]$.

Magnesium dissolution rates have the highest correlation with nickel $\left(\mathrm{R}^{2}=0.98\right)$ and iron $\left(\mathrm{R}^{2}=0.91\right)$ dissolution values (Fig. 7). Manganese, which is one of the easiest soluble material in $\mathrm{HCl}$, and chromium, which is one of the hardest soluble material in $\mathrm{HCl}$, dissolution values ( $\mathrm{R}^{2}=0.87$ and 0.72 , respectively) show the lower correlation with magnesium

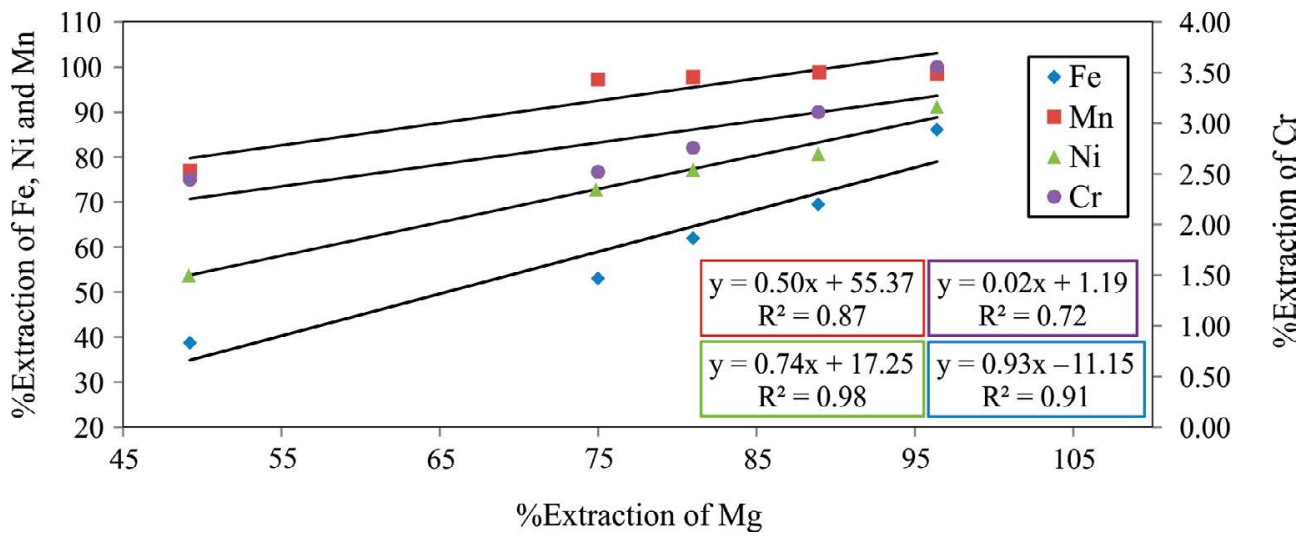

Fig. 7. Extraction correlation for magnesium, iron, chromium and nickel in the $\mathrm{HCl}$ leaching (Extraction values were taken from Fig. 6c)

Rys. 7. Korelacja ekstrakcji magnezu, żelaza, chromu i niklu w ługowaniu $\mathrm{HCl}$ (wartości ekstrakcyjne pobrano z rys. 6c) 
dissolution values by comparison with the $\mathrm{Ni}$ and $\mathrm{Fe}$ dissolutions. It can be deduced that the selective extraction of metals from these solid samples except for chromium is not possible by leaching. The metals can be obtained from the leach solution by solvent extraction, selective precipitation or the other methods after the solid/liquid separation.

The solid residue generated after leaching was in the form of amorphous silica which is known for characteristic diffused broad peak at 2 theta: 22.141 (Fig. 8; Table 5) (Javed et al. 2010). Basically, insoluble contents in this residue were chromite and antigorite minerals.

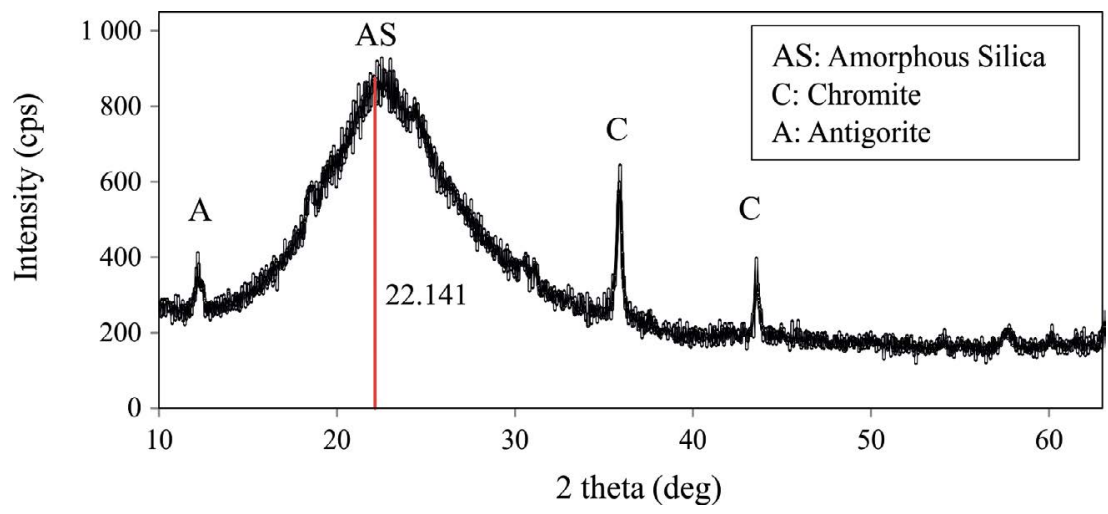

Fig. 8. XRD Pattern of the leach residual

Rys. 8. Dyfraktogram rentgenowski XRD pozostałości po ługowaniu

Table 5. Composition of the leach residual at optimum conditions

Tabela 5. Skład pozostałości ługu w warunkach optymalnych

\begin{tabular}{|c|c|c|c|c|c|c|c|}
\hline Component & $\mathrm{SiO}_{2}$ & $\mathrm{MgO}$ & $\mathrm{Fe}_{2} \mathrm{O}_{3}$ & $\mathrm{Cr}_{2} \mathrm{O}_{3}$ & $\mathrm{Al}_{2} \mathrm{O}_{3}$ & $\mathrm{NiO}$ & $\mathrm{MnO}$ \\
\hline$\%$ & 86.28 & 6.14 & 3.39 & 2.35 & 1.81 & 0.01 & 0.02 \\
\hline
\end{tabular}

\subsection{Magnetic Separation Tests Following the Leaching}

High intensity wet magnetic separation was carried out at the previous optimum magnetic separation conditions again in order to remove metallic impurities from the leach residuals (Fig. 9). Amorphous silica grade was raised to $96.5 \% \mathrm{SiO}_{2}$ with $84.38 \%$ total recovery yield after consecutive two magnetic separations (Table 6). 


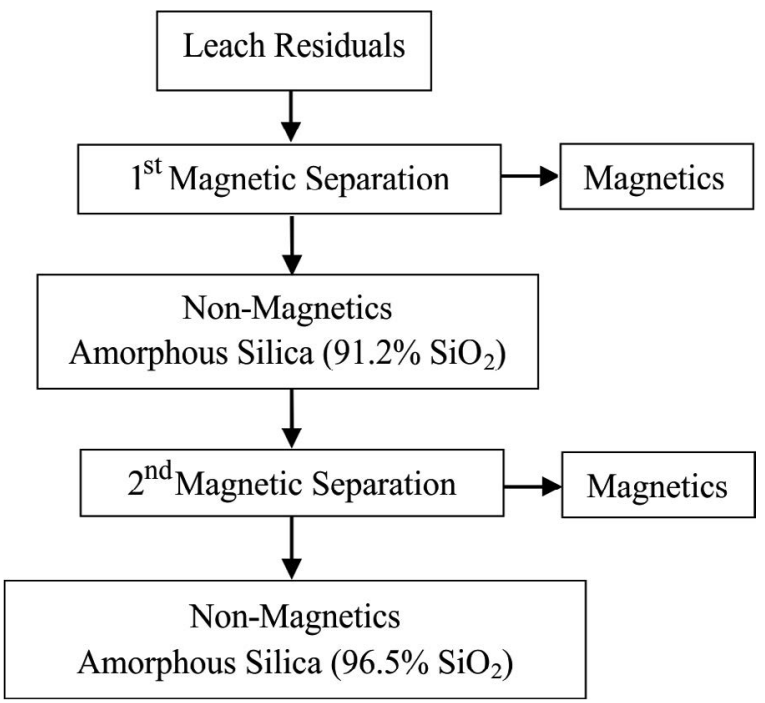

Fig. 9. Flow chart of the additional magnetic separations

Rys. 9. Schemat blokowy dodatkowych separacji magnetycznych

Table 6. Composition of the non-magnetic material after the separation twice

Tabela 6. Skład materiału niemagnetycznego po dwukrotnej separacji

\begin{tabular}{|c|c|c|c|c|c|}
\hline Component & $\mathrm{SiO}_{2}$ & $\mathrm{MgO}$ & $\mathrm{Cr}_{2} \mathrm{O}_{3}$ & $\mathrm{Al}_{2} \mathrm{O}_{3}$ & $\mathrm{Fe}_{2} \mathrm{O}_{3}$ \\
\hline$\%$ & 96.50 & 1.19 & 1.07 & 1.00 & 0.24 \\
\hline
\end{tabular}

\subsection{Precipitation}

Magnesium hydroxide was fed into a predetermined volume of the leach solution in order to remove the impurities and the solution $\mathrm{pH}$ was raised by this route. When $\mathrm{Mg}(\mathrm{OH})_{2}$ was added to the leach solution, not only concentration of magnesium ions increased but also impurities except calcium ions, which generally precipitate with magnesium ions above $\mathrm{pH} 10$, precipitated as their hydroxide forms. Different $\mathrm{pH}$ values were chosen to specify an optimal $\mathrm{pH}$ value (Fig. 10,11). The contents of the leach solution obtained after solid/liquid separation is seen in Table 7. Solid $\mathrm{MgO}$ could have used instead of $\mathrm{Mg}(\mathrm{OH})_{2}$ by providing the same effect. $\mathrm{NH}_{3}$ or $\mathrm{NaOH}$ could be selected for upgrading the $\mathrm{pH}$, but contamination possibility of magnesium chloride solution with impurities such as $\mathrm{Na}$ and $\mathrm{N}$ eliminated these options. 
Table 7. Contents of the purified magnesium chloride solution at $\mathrm{pH} 8$

Tabela 7. Zawartość oczyszczonego roztworu chlorku magnezu w pH 8

\begin{tabular}{|c|c|c|c|c|c|c|}
\hline Element & $\mathrm{Mg}$ & $\mathrm{Fe}$ & $\mathrm{Cr}$ & $\mathrm{Mn}$ & $\mathrm{Ni}$ & $\mathrm{Ca}$ \\
\hline $\mathrm{mg} / \mathrm{L}$ & 12040 & - & - & 4.42 & 0.09 & 280 \\
\hline
\end{tabular}

As a result of the precipitation tests, the solution obtained from solid/liquid separation at $\mathrm{pH} 8$ was used in the following crystallization tests.

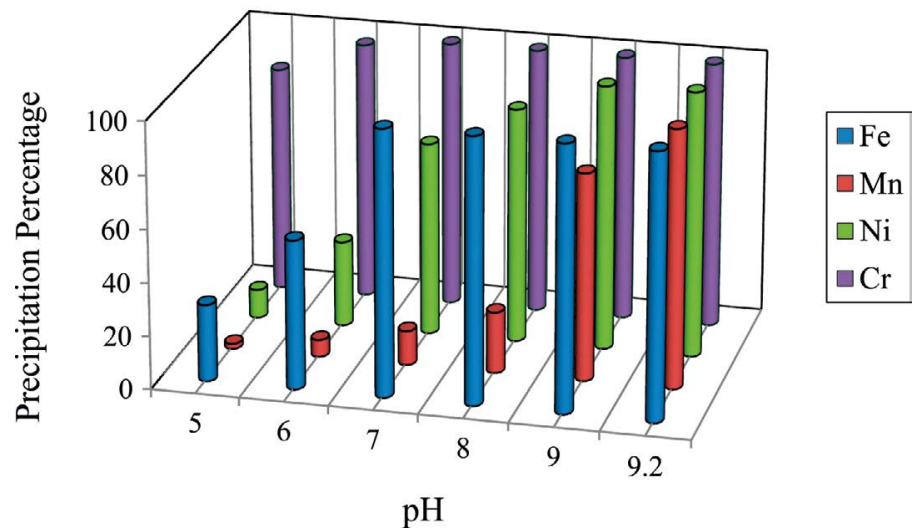

Fig. 10. Precipitation percentage of the impurities by $\mathrm{pH}$

Rys. 10. Udział procentowy osadów zanieczyszczeń w zależności od pH

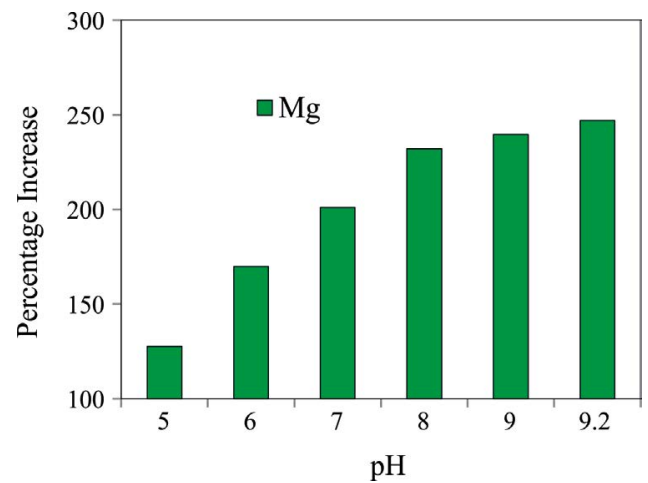

Fig. 11. Percentage increase of the magnesium content by $\mathrm{pH}$

Rys. 11. Procentowy wzrost zawartości magnezu w zależności od pH 


\subsection{Crystallization}

The purified magnesium chloride solution taken from previous $\mathrm{pH}$ increasing stage was mixed with solid $\mathrm{KOH}$ pellets at $90^{\circ} \mathrm{C}$, stoichiometrically. After obtaining the clear and colourless solution, the final solution was evaporated between $90-10^{\circ} \mathrm{C}$ by controlled heating. Finally, white residual was obtained and ground in order to analyse.

It was observed that XRD peaks of the synthesized material in Fig. 12 matched with the carnallite mineral (Mineralienatlas.de 2014; Mindat.org 2014). Also, chemical analysis of this material confirmed that the mineral carnallite was synthesized (Table 8).

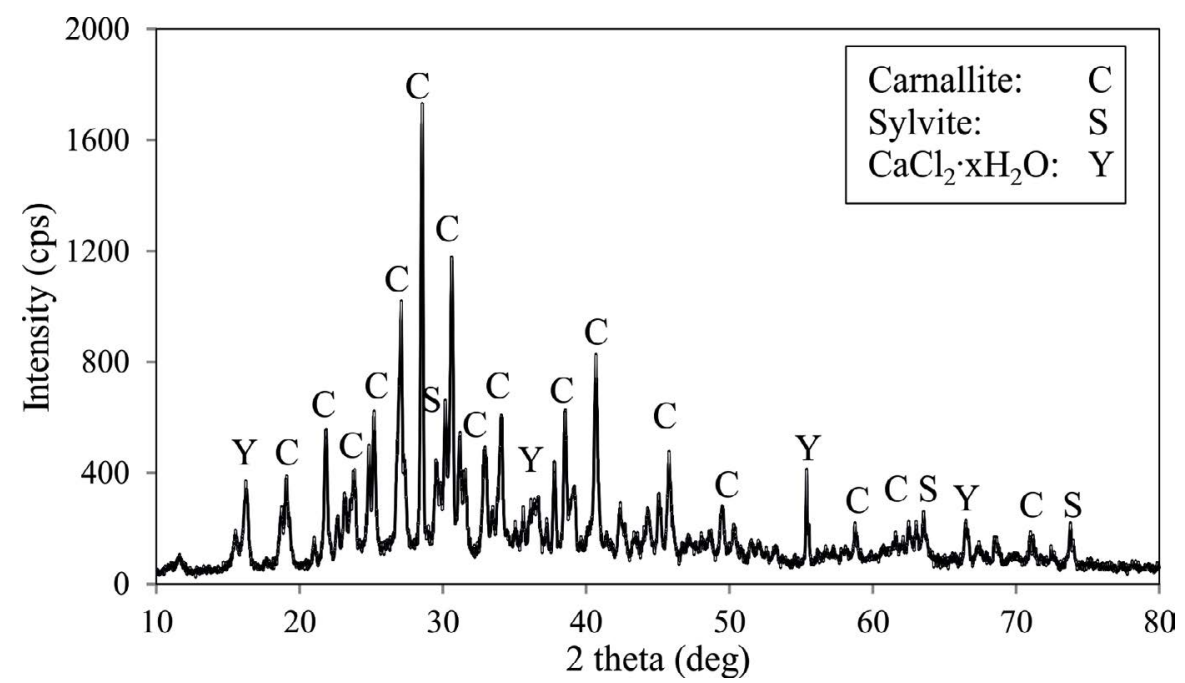

Fig. 12. XRD pattern of the synthesized carnallite

Rys. 12. Dyfraktogram rentgenowski XRD syntetycznego karnalitu

Table 8. Chemical analysis of the synthesized carnallite

Tabela 8. Analiza chemiczna syntetyzowanego karnalitu

\begin{tabular}{|c|c|}
\hline Compound & $\%$ \\
\hline $\mathrm{MgO}$ & 17.40 \\
\hline $\mathrm{Cl}$ & 34.60 \\
\hline $\mathrm{K}_{2} \mathrm{O}$ & 21.40 \\
\hline $\mathrm{CaO}$ & 0.87 \\
\hline $\mathrm{MnO}$ & 0.04 \\
\hline $\mathrm{H}_{2} \mathrm{O}$ & 25.69 \\
\hline
\end{tabular}




\section{Conclusions}

Present study indicates that synthetic carnallite can be prepared from chromite ore beneficiation plant tailings by extracting and purifying the magnesium content in these tailings. Besides, high grade amorphous silica $\left(\mathrm{SiO}_{2}>96 \%\right)$, which is suitable raw material for the production of photovoltaic solar panels because of not containing boron and phosphorus, can be obtained by $\mathrm{HCl}$ leaching as leach residual. For these purposes, optimum magnetic separation, leaching and precipitation parameters were determined.

Chromite cut-off grade plummeted to $4-5 \% \mathrm{Cr}_{2} \mathrm{O}_{3}$ in Aladag district. In this context, it can be said that the magnetic material, which is obtained from the first single stage magnetic separation with $6.10 \% \mathrm{Cr}_{2} \mathrm{O}_{3}$ grade and $85.75 \% \mathrm{Cr}_{2} \mathrm{O}_{3}$ recovery yield, can be fed to the concentration plants in order to upgrade the $\mathrm{Cr}_{2} \mathrm{O}_{3}$ grade to saleable $\mathrm{Cr}_{2} \mathrm{O}_{3}$ grade $\left(\mathrm{Cr}_{2} \mathrm{O}_{3}>46 \%\right)$.

It is thought that required additional $\mathrm{Mg}(\mathrm{OH})_{2}$ amount and $\mathrm{HCl}$ concentration in the leaching stage can be reduced by high pressure leaching. Also, high intensity dry magnetic separation can be used for removal of the magnetic particles in the amorphous silica product in order to upgrade the $\mathrm{SiO}_{2}$ content. Studies about these options are planned for the further researches.

\section{Acknowledgement}

This study was supported in part by the Institute of Natural and Applied Sciences of Cukurova University (Project id: MMF2012YL24).

\section{REREFENCES}

Agacayak et al. 2007 - Agacayak, T., Zedef, V. and Aydogan, S. 2007. Beneficiation of Low-grade Chromite Ores of Abandoned Mine at Topraktepe, Beyşehir, SW Turkey. Acta Montanistica Slovaka 12, pp. 323-327.

Aslan, N. and Kaya, H. 2009. Beneficiation of Chromite Concentration Waste by Multi-Gravity Separator and High-Intensity Induced-Roll Magnetic Separator. The Arabian Journal for Science and Engineering 34(2B), pp. 285-297.

Bron et al. 1967 - Bron, V.A., Stepanova, I.A. and Kudryavtseva, T.N. 1967. Effect of Degree of Serpentine Formation in Dunite on Its Properties and Structure Change During Heating. Refractories 8(9-10), pp. 553-558.

Chen et al. 2014 - Chen, G., Wang, X., Du, H., Zhang, Y., Wang, J., Zheng, S. and Zhang, Y. 2014. A New Metallurgical Process for the Clean Utilization of Chromite Ore. International Journal of Mineral Processing 131, pp. 58-68.

Cicek, T. and Cocen, I. 2002. Applicability of Mozley Gravity Separator (MGS) to Fine Chromite Tailings of Turkish Chromite Concentrating Plants. Minerals Engineering 15, pp. 91-93.

Dutrizac et al. 2000 - Dutrizac, J.E., Chen, T.T. and White, C.W. 2000. Fundamentals of Serpentine Leaching in Hydrochloric Acid Media. [In:] Kaplan, H.I. et al. eds. Magnesium Technology 2000. Nashville, 2000. TMS (Mineral Metals Materials Society) Publication, pp. 41-52.

El-leef et al. 2012 - El-leef, E.M.A., Abeidu, A.E.M., Mahdy, A.E.M. 2012. Utilization of Serpentine Ore for Production of Magnesium Sulphate. World Journal of Engineering and Pure \& Applied Sciences 2(2), pp. 31-39.

Fedorockova et al. 2012 - Fedorockova, A. Hreus, M. Racschman, P. and Sucik, G. 2012. Dissolution of Magnesium from Calcined Serpentinite in Hydrochloric Acid. Minerals Engineering 32, pp. 1-4. 
Gao et al. 2014 - Gao, W., Wen, J. and Li, Z. 2014. Dissolution Kinetics of Magnesium from Calcined Serpentine in $\mathrm{NH}_{4} \mathrm{Cl}$ Solution. Industrial \& Engineering Chemistry Research 53(19), pp. 7947-7955.

Geveci et al. 2002 - Geveci, A., Topkaya, Y. and Ayhan, E. 2002. Sulphuric Acid Leaching of Turkish Chromite Concentrate. Minerals Engineering 15(11), pp. 885-888.

Gladikova et al. 2008 - Gladikova, L.A., Teterin, V.V. and Ovchinnikova, N.B. 2008. Purification of Magnesium Chloride Solution Used for Carnallite Synthesis. Russian Journal of Applied Chemistry 81(5), pp. 883-885.

Guney et al. 2001 - Guney, A., Onal, G. and Atmaca, T. 2001. New Aspect of Chromite Gravity Tailings Re-processing. Minerals Engineering 14(11), pp. 1527-1530.

Javed et al. 2010 - Javed, S.H., Naaved, S., Feroze, N., Zafar, M. and Shafaq, M. 2010. Crystal and Amorphous Silica from $\mathrm{KMnO}_{4}$ Treated and Untreated Rice Husk. Journal of Quality and Technology Management VI, pp. $81-90$.

Khattak et al. 2001 - Khattak, C.P., Joyce, D.B. and Schmid, F. 2001. Production of Solar Grade (SoG) Silicon by Refining Liquid Metallurgical Grade (MG) Silicon, National Renewable Energy Laboratory (NREL) - Subcontractor Final Report, 40 pp.

Mindat.org. Mineral Information of Carnallite. [Online] Available at: http://www.mindat.org/min-906.html [Accessed: 13.12.2014].

Mineral Research \& Exploration General Directorate (MTA), Mineral Resources of Adana, [Online] Available at: http://www.mta.gov.tr/v2.0/turkiye maden/maden potansiyel 2010/Adana Madenler.pdf [Accessed: 21.02.2015]

Mineralienatlas.de. Mineral Information of Carnallite. [Online] Available at: https://www.mineralienatlas.de/lexikon/index.php/MineralData?mineral=Carnallite [Accessed: 13.11.2014].

Polmear, I.J. 1999. Introduction: History, Production, Applications and Markets [In:] Avedesian, M.M. and Laker, H. eds. Magnesium and Magnesium Alloys. ASM International, Ohio, pp. 3-6.

Spectroscopyonline.com. Quick and Easy Dissolution of Chromite Ores. [Online] Available at: http://www.spectroscopyonline.com/quick-and-easy-dissolution-chromite-ores-ferrochromes-and-chromium -slags-icp-oes-without-using-hf-or [Accessed: 13.06.2014].

Strelets, Kh.L. 1977. Electrolytic Production of Magnesium. Springfield, 325 pp.

Teir et al. 2007 - Teir, S., Revitzer, H., Eloneva, S., Fogelholm, C.J. and Zevenhoven, R. 2007. Dissolution of Natural Serpentinite in Mineral and Organic Acids. International Journal of Mineral Processing 83, pp. 36-46.

Top, S. and Yildirim, M. 2015. Magnesium Sulphate $\left(\mathrm{MgSO}_{4}\right)$ Synthesis from Chromite Concentration Plant Tailings. Madencilik 54(1), pp. 37-46 (in Turkish).

Tripathy et al. 2013 - Tripathy, S.K., Murthy, Y.R. and Singh, V. 2013. Characterization and Separation Studies of Indian Chromite Beneficiation Plant Tailing. International Journal of Mineral Processing 122, pp. 47-53.

Vapur et al. 2014 - Vapur, H., Top, S., Demirci, S., Develi, Y. and Sirkeci, A.A. 2014. Investigation of the Enrichment Possibilities of Teckrom Mining Company Tailings. [In:] Ipekoglu, U. et al. eds. Proceedings of $14^{\text {th }}$ International Mineral Processing Symposium. Kusadasi, 15-17 October, 2014. Turkish Mining Development Foundation, pp. 183-190

Watson et al. 2000 - Watson, K., Ficara, P., Charron, M., Peacey, J., Chin, E.W. and Bishop, G., The Magnola demonstration plant: A Valuable Investment in Technology Development and Improvement [In:] Kaplan, H.I. et al. eds. Magnesium Technology 2000. Nashville, 2000. TMS (Mineral Metals Materials Society) Publication, pp. 27-30.

Xakalashe, B.S. and Tangstad, M. 2011. Silicon Processing: from Quartz to Crystalline Silicon Solar Cells [In:] Jones, R.T. and Hoed, P.D. eds. Southern African Pyrometallurgy 2011. Southern African Institute of Mining and Metallurgy, Johannesburg, pp. 83-99.

Zengin et al. 2009 - Zengin, M., Gokmen, F., Yazici, M.A. and Gezgin, S. 2009. Effects of Potassium, Magnesium and Sulphur Containing Fertilizers on Yield and Quality of Sugar Beets (Beta vulgaris L.). Turkish Journal of Agriculture and Forestry 33, pp. 495-502. 


\title{
WYTWARZANIE SYNTETYCZNEGO KARNALITU I AMORFICZNEJ KRZEMIONKI
} Z ODPADÓW WZBOGACANIA RUD CHROMITOWYCH

\author{
Słowa kluczowe \\ syntetyczny karnalit, bezpostaciowa krzemionka, wzbogacanie magnetyczne, odzysk
}

\section{Streszczenie}

W artykule przedstawiono badania możliwości wytwarzania karnalitu $\left(\mathrm{MgCl}_{2} \cdot \mathrm{KCl} \cdot 6 \mathrm{H}_{2} \mathrm{O}\right)$ i bezpostaciowej krzemionki $\left(\mathrm{SiO}_{2}\right)$ z odpadów z zakładów procesu wzbogacania chromitów, które zawierają 3,44\% wag. chromitu $\left(\mathrm{Cr}_{2} \mathrm{O}_{3}\right)$ i 30,55\% wag. tlenku magnezu (MgO). W skali laboratoryjnej do usuwania materiałów magnetycznych, takich jak: chromit, żelazo (II) i minerały manganowe (II) zastosowano wzbogacanie mokre w separatorach magnetycznych o wysokiej intensywności. Około $85,75 \%$ chromitu, $91,22 \% \mathrm{MnO}$ i $64,71 \% \mathrm{Fe}_{2} \mathrm{O}_{3}$ usunięto metodą jednoetapowej separacji magnetycznej. Po wzbogacaniu magnetycznym odzysk hydrometalurgiczny został zainicjowany przez ługowanie odpadów kwasem chlorowodorowym $(\mathrm{HCl})$. Amorficzne cząstki krzemionki i inne substancje stałe oddzielono od roztworu ługującego przez filtrację. Z roztworu ługowanego wytrąciły się zanieczyszczenia przez wzrost pH dzięki zawartemu wodorotlenkowi magnezu $\left(\mathrm{Mg}(\mathrm{OH})_{2}\right)$. Oczyszczony roztwór chlorku magnezu $\left(\mathrm{MgCl}_{2}\right)$ zmieszano z wodorotlenkiem potasu $(\mathrm{KOH})$ w stosunku stechiometrycznym. Zgodnie z XRD i analizą chemiczną, syntetyczny karnalit syntetyzowano przez kontrolowane ogrzewanie tego roztworu w temperaturze $90-100^{\circ} \mathrm{C}$. Również odzysk $84,38 \%$ amorficznej krzemionki o zawartości $96,5 \% \mathrm{SiO}_{2}$ uzyskano przez dodatkowe magnetyczne wzbogacanie.

\section{PREPARATION OF SYNTHETIC CARNALLITE AND AMORPHOUS SILICA FROM CHROMITE BENEFICIATION PLANT TAILINGS}

\author{
Keywords \\ synthetic carnallite; amorphous silica; mineral processing; recovery.
}

\section{Abstract}

In this paper, synthetic carnallite $\left(\mathrm{MgCl}_{2} \cdot \mathrm{KCl} \cdot 6 \mathrm{H}_{2} \mathrm{O}\right)$ and amorphous silica $\left(\mathrm{SiO}_{2}\right)$ preparation possibilities were investigated by utilizing chromite beneficiation plant tailings which contain $3.44 \%$ chromite $\left(\mathrm{Cr}_{2} \mathrm{O}_{3}\right)$ and $30.55 \%$ magnesium oxide $(\mathrm{MgO})$ by weight. Firstly, laboratory scale high intensity wet magnetic separator was applied for removing the magnetic materials such as chromite, iron (II) and manganese (II) minerals in the tailings. About $85.75 \%$ of chromite, $91.22 \%$ of $\mathrm{MnO}$ and $64.71 \%$ of $\mathrm{Fe}_{2} \mathrm{O}_{3}$ were removed by single stage magnetic separation. After the magnetic separation, hydrometallurgical recovery was initiated by leaching of the tailings with hydrochloric acid $(\mathrm{HCl})$. Amorphous silica particles and the other solids were separated from the leach solution by filtration. Impurities were precipitated from the leach solution by elevating the solution $\mathrm{pH}$ via magnesium 
hydroxide $\left(\mathrm{Mg}(\mathrm{OH})_{2}\right)$ adding. The purified magnesium chloride $\left(\mathrm{MgCl}_{2}\right)$ solution was mixed with potassium hydroxide $(\mathrm{KOH})$ at stoichiometric ratio. According to the XRD and chemical analysis, the synthetic carnallite was synthesized by controlled heating of this solution at $90-100^{\circ} \mathrm{C}$. Also, the amorphous silica with $96.5 \% \mathrm{SiO}_{2}$ content and $84.38 \%$ recovery yield was obtained by additional magnetic separation treatment. 
